\title{
Siting the sun set
}

In the United States, the Energy Research and Development Adminis tration ( $E R D A)$ has faced numerous complications over its solar energy plans. And, as Colin Norman reports from Washington, problems remain

IT HAS been several years since a major political scrap broke out in the United States over the location of a major new research facility, for the good reason that there haven't been many new facilities established recently. But in the next few months every state is expected to compete for a scientific prize-a Solar Energy Research Institute, to be established by the Energy Research and Development Administration (ERDA).

The location of the institute won't be the only source of dispute, however, for last week ERDA announced plans for the facility which suggest that it will be a much more modest enterprise than many of its proponents had envisaged.

Plans for the institute have been through a long, and difficult, gestation period. Approved by Congress as part of a bill passed in November 1974, the institute, known by its acronym SERI, was expected to be a major national laboratory for planning and carrying out government research on solar energy. Congress left ERDA to decide exactly what the role and scope of SERI should be, and it also asked the National Academy of Sciences to assist ERDA in the planning.

When the bill was approved, it was generally assumed by SERI's congressional sponsors that the institute would rapidly evolve into the focal point for the government's solar energy programme, and that it would develop into a major facility along the lines of ERDA's nuclear laboratories such as Oak Ridge or Los Alamos. And that assumption was reinforced by the Academy, which last October recommended that SERI should be provided with a budget of about $\$ 50$ million and a staff of 630 by 1980 .

\section{Modest effort}

ERDA officials also hoped to get moving quickly on a large facility but, following a series of disputes with the White House culminating in the resignation of a senior ERDA administrator, the agency last week announced plans for a much more modest effort. The plans, set out in a formal invitation for public and private institutions to bid for a contract to establish SERI, envisage a modest beginning over the next three years, with no absolute guarantee that the institute will ever develop into ERDA's leading solar energy laboratory.

ERDA, in short, has asked for proposals to establish a solar energy management and research team at an existing institution, with a budget of between $\$ 4$ and $\$ 6$ million for the first year, rising to $\$ 10-20$ million in the third year. In addition, ERDA has asked the bidders to propose a nearby site for a larger, separate facility into which SERI could move at a later date if necessary. The idea is to provide for deliberate, phased growth possibly-though not definitely-to a major national laboratory in the early 1980s.

Under ERDA's direction, SERI will provide analysis and planning for research and development programmes on solar energy, ranging from direct use of sunlight for heating and cooling buildings to electricity generation, wind power, and bioconversion. In addition, SERI will perform some research and development itself. Dr Robert Hirsch, acting assistant ERDA administrator for solar, geothermal and advanced energy, said last week that he expects a contractor and location to be chosen in December, and that SERI will begin operations on January 1, 1977. A decision on whether or not SERI will move to a large, permanent site is expected in two or three years, he added.

\section{Cautious approach}

ERDA arrived at that pared down proposal after the White House Office of Management and Budget (OMB) had vetoed its earlier plans for a more ambitious facility. OMB, understandably, argued that ERDA should proceed with caution, moving to a large facility only if the need for a major enterprise is demonstrated. OMB's reluctance to move with dispatch on SERI, and on other parts of the solar energy programme, led to the resignation in January of John M. Teem, Hirsch's predecessor in charge of ERDA's solar energy efforts.

The cautious approach embodied in the proposals is likely to provide considerable ammunition for solar energy proponents, who have long argued that the solar programme has been held back in the past few years while funding for nuclear energy has been growing by leaps and bounds. Though government expenditures on solar energy and development have grown from $\$ 200,000$ in 1972 to an anticipated $\$ 116$ million next year, the total proposed for the nuclear programme next year amounts to nearly $\$ 3,000$ million. Solar energy proponents are particularly fond of pointing out that the breeder reactor alone-which, like some uses of solar energy isn't expected to make any contribution to energy supplies until the 1990samounts to $\$ 880$ million next year.

Nevertheless, since SERI is likely to be a prestigious institute which will attract top-level talent and perhaps some associated industry, there is likely to be fierce competition between the states for the contract. The competition in fact started several months ago when several states set up committees to plan their strategies for securing SERI. ERDA has also been inundated with inquiries from interested institutions.

The last tussle over the location of a major research facility in the United States was during the Johnson Administration, when the National Accelerator Laboratory was up for grabs. In the end, that facility was located in Illinois because, according to widespread speculation, Johnson needed the support of Illinois Senator Everett Dirksen, then Senate minority leader, on several key items of legislation. ERDA, however, is anxious to avoid any suspicion that such squalid political deals will decide the site for SERI, and it has insisted that the location will be chosen on strictly scientific and other "factual" criteria.

\section{ERDA taken aback}

ERDA officials were therefore somewhat taken aback when President Ford told a Colorado energy symposium last September that Arizona, New Mexico and Florida are the leading contenders to house SERI. Ford, moreover, told officials from Florida's Brevard County recently that their region would receive "excellent consideration" as the site for the institute.

$\mathrm{Be}$ that as it may, Hirsch said last week that SERI could be located anywhere in the United States, and that he expects to receive proposals from all 50 states. He noted that the institute will be performing a range of work on solar energy and that some technologies (generation of electricity from wind, for example) don't need large quantities of sunlight. It should not therefore be assumed that SERI must be located in the sunny southwest, he said.

Proposals must be submitted to ERDA by July 15 , a site selection board composed of ERDA officials will evaluate them, and a final decision will be taken by ERDA administrator Robert C. Seamans, Jun. in December. 